\title{
Formation of the Professional and Didactic Culture of the Future Teacher
}

\author{
Alsu Linarovna Mirzagitova ${ }^{1}$, Linar Gimazetdinovich Akhmetov
}

\begin{abstract}
:
Problem Statement: Didactic training is a major component of the professional development of future teachers. However, the problem of the formation of their professional culture has not been sufficiently elaborated.

Purpose of Study: A critical analysis of the literature has showed significant weakness of the culturological component of future teachers' didactic training.

Methods: It is the cultural approach that includes systemic, competence-based, personal, axiological and other approaches to professional development.

Findings and results: The paper actualizes the concept of "pedagogical responsibility" and considers the basic aspects of the professional and didactic culture of future history teachers. Conclusions and Recommendations: Under conditions of information abundance, an important feature of any human being is critical thinking as the ability to interpret and analyze facts, to build arguments and to draw conclusions.
\end{abstract}

Key Words: professional and didactic culture; critical thinking; future teacher's training; skills; algorithm.

\footnotetext{
${ }^{1}$ 423602, Tatarstan Republic, Elabuga, Department of Theory and Methods of Teaching Law and Jurisprudence, Elabuga Institute of Kazan Federal University, Elabuga, Tatarstan Republic, Russian Federation, mirzagitova-alsu@mail.ru,89874163664
} 


\section{Introduction}

Contemporary reality is characterized by seemingly contradictory processes of integration and disintegration, globalization and localization that permeate almost all levels of social relations, from interpersonal to international. Transformations in the geopolitical arena lead to the changes in the political, socio-economic and spiritual life of society. The changing of people's worldview entails a new formulation of the question about the meaning of life, human values and man's place in the world. Another characteristic feature of contemporary reality is its uncontrolled media coverage. The internet, television, print media are often used for remote control of mass consciousness.

Today, the system of general education requires professionals to have a high level of professional competence and skills of organizational, educational and administrative work in a pupils' group.

Under these conditions, there is a need for professional training of teachers who can objectively and critically evaluate information and validity, independently conduct causal relationships and give a reasoned assessment of the events using only facts. A professional teacher should be aware of the responsibility for the results of their professional activity, have a stable civil position and a formed scientific worldview. The combination of these qualities and skills is the basis of the didactic culture of the future teacher.

Thus, taking into account the requirements of society as a whole and a modern education system in particular, there is a need to develop modern technologies which would allow shaping the professional and didactic culture of future teachers and providing an objective comprehensive assessment of the level of its formation.

On the socio-pedagogical level, the relevance of this problem is based on the necessity to improve the content of future teachers' training with regard to the requirements of time. On the scientific and theoretical level, it is expressed in the absence of the elaborated conditions for the formation of professional and didactic culture. On the methodological level, the relevance of this problem stems from the need to develop specific guidelines in order to facilitate the formation of professional and didactic culture of the future teacher.

Drastic changes in the international, political, social, economic and other spheres of society determined the advanced development of the education system on the basis of the intensification of the educational process (Samokhin, 2012).

Contemporary education should be aimed at ensuring an adequate level of general and professional culture of each individual, the level of mental development of the individual, professional qualification and professional competence. This is impossible without focusing on two important aspects of the educational process: the 
personality of the learner, including his or her personal and professional qualities, and the pedagogical system that defines the objectives, content and methods of the formation of the personality (Levina, Akhmetov, Latipova, Mirzagitova, Mirzanagimova, Latipov, \& Masalimova, 2015).

Let us consider this problem using a specific example of training of the future teacher of history and peculiarities of the formation of his or her professional and didactic culture.

Historical consciousness is not just a collection of people's knowledge about the past but also their valuable attitude towards historical facts and ideas about the influence of the past on the present and the future. History, as well as many social and humanitarian disciplines, to some extent always performs an ideological function in addition to a cognitive one. Every time the image of the past is modified by the present, and there is the reinterpretation of historical facts and the transformation of the very structure of objects of historical interest. This leads to a high responsibility of history teachers in the process of historical knowledge transfer to pupils (Hendry, Frommer, \& Walker, 1999).

On the basis of the analysis of pedagogical literature, the following components of pedagogical responsibility can be identified in the broadest sense:

1. Legal responsibility. Its content is set forth in the Russian legislation as the "duty of the teacher stipulated by legal norms to undergo adverse consequences of the non-performance or improper performance of duties assigned to him".

2. Moral responsibility. In psychological and educational literature, there is no single definition of the "moral responsibility of the teacher". However, its content, in general terms, requires the self-examination of his or her activity, selfreport on the results of this activity, awareness of the social significance and moral obligation to the community.

3. Pedagogical responsibility in the narrow sense includes the provision of safety and health of children in the pedagogically organized activities, as well as the responsibility for the essence and content of training, education and development (Mirzagitova, Mukhametgaliyeva, \& Tirigulova, 2015).

The need to study the professional and didactic culture of the future history teacher also derives from the requirements of the modern socio-educational situation to pedagogical activity. Its specificity is that it constantly reproduces new conditions, means and organizational forms of training. Professional and didactic culture is a prerequisite for pedagogical activity that contributes to further formation and selfdevelopment of professional and personal qualities of the teacher of history (Mirzagitova, \& Akhmetov, 2015).

Pedagogy researchers have actively discussed the problem of the development of professional and pedagogical culture and its forms, including: 
- technology (M.M. Levina, A.I. Uman), communicative (A.B. Mudrik), historical and pedagogical (A.K. Kolesov);

- aesthetic (L.E. Babich, G.A. Petrova), ethical (E.A. Grishin, E.G. Silyaeva, G.S. Yakovleva), moral (E.P. Bayeva, M.M. Mukombayeva, N.E. Schurkova), individually-creative (Yu.K. Babansky, V.I. Zagvyazinsky, V.A. Sukhomlinsky, V.C. Turbovsky);

- culture of academic work (T.M. Davydenko, I.I. Zaretskaya, V.I. Lozova, T.I. Shamova), psychological (N.I. Isayeva, A.K. Markova, F.M. Mukhometzyanova);

- formation of the didactic culture of the general gymnasium teacher studied by N.M. Fatyanova;

- development of the didactic culture of the technical college teacher analyzed by O.A. Igumnov.

The individual aspects of the future teacher's training have been reviewed by L.G. Akhmetov, I.M. Faizrakhmanov and A.L. Faizrakhmanova. Their works describe in detail the issues of training of a competitive teacher. The use of communicative interaction is considered as a system-forming factor of the preparedness of students of the teacher's training college to competitive relations. It acts as a direct or indirect communication between two or more people related to the transfer of information or the exchange of other results of individual activity (Akhmetov, Faizrakhmanov, \& Faizrakhmanova, 2013; Akhmetov, Faizrakhmanov, \& Faizrakhmanova, 2014).

Mirzagitova and Akhmetov (2015) in their paper "Self-development of pedagogical competence of future teacher" analyze the conditions necessary for the formation of a motivation to develop future teachers' competence. They also consider the basic stages in the process of pedagogical competence formation (Mirzagitova, \& Akhmetov, 2015).

However, it should be noted that so far there are no works devoted to the complex research of the formation of professional and didactic culture of the future teacher. It is important to note that the modern educational process is characterized by scales. Whereas previously didactics was limited to a lesson and a learning process itself, today teachers face a deeper problem - to provide an integrated educational process, including the implementation of educational, disciplinary and developmental problems.

\section{Materials and Methods}

To make recommendations on the organization of the most effective training of students-future teachers for their professional activity we conducted a research of the pedagogical activity of teachers.

\section{Stage 1: Collection of primary information}


In teachers' training institutions, a curriculum provides teaching practice in the third and fourth years of study. During this practice, students were suggested to prepare an analysis of the pedagogical activity of their teachers. Firstly, this analysis involved the determination of the teaching paradigm. To do this, students were provided with the matrix determining the ways of organizing pupils' activities in the authoritarian and humanistic teaching paradigms, elaborated by Ksenzova G.Y. (Table 1).

Table 1. Matrix of the Determination of Ways of Organizing Pupils' Activities in the Authoritarian and Humanistic Teaching Paradigms Suggested by Ksenzova (Ksenzova, 2004).

\begin{tabular}{|l|l|l|}
\hline Activity components & $\begin{array}{l}\text { Authoritarian method of } \\
\text { teaching }\end{array}$ & $\begin{array}{l}\text { Humanistic method of } \\
\text { teaching }\end{array}$ \\
\hline $\begin{array}{l}\text { Purpose - a model of the } \\
\text { desired future, the expected } \\
\text { result }\end{array}$ & $\begin{array}{l}\text { Set by the teacher, can be } \\
\text { declared by the person } \\
\text { replacing him or her }\end{array}$ & $\begin{array}{l}\text { In the process of } \\
\text { problematization, pupils' } \\
\text { inner acceptance of the } \\
\text { purpose of the upcoming } \\
\text { activity is provided }\end{array}$ \\
\hline $\begin{array}{l}\text { Motives - a driving force } \\
\text { for activities }\end{array}$ & $\begin{array}{l}\text { External motives are used } \\
\text { into account }\end{array}$ \\
\hline $\begin{array}{l}\text { Means - ways of the } \\
\text { implementation of activities }\end{array}$ & $\begin{array}{l}\text { Determined by the teacher, } \\
\text { mostly traditional means are } \\
\text { used, regardless of the } \\
\text { purpose }\end{array}$ & $\begin{array}{l}\text { The choice of learning means } \\
\text { (relevant for the purpose) is } \\
\text { shared with pupils }\end{array}$ \\
\hline $\begin{array}{l}\text { Actions - the main element } \\
\text { of the activity }\end{array}$ & $\begin{array}{l}\text { Non-alternative actions } \\
\text { provided by the teacher are } \\
\text { undertaken }\end{array}$ & $\begin{array}{l}\text { A range of actions is } \\
\text { consistent with the capacity } \\
\text { of pupils }\end{array}$ \\
\hline $\begin{array}{l}\text { Result - a material or } \\
\text { spiritual product }\end{array}$ & $\begin{array}{l}\text { The external result can be } \\
\text { seen - mainly the level of } \\
\text { knowledge acquisition }\end{array}$ & $\begin{array}{l}\text { The main thing is the } \\
\text { personal positive changes } \\
\text { provided in the process of } \\
\text { learning }\end{array}$ \\
\hline $\begin{array}{l}\text { Assessment }- \text { a criterion of } \\
\text { goal achievement }\end{array}$ & $\begin{array}{l}\text { Comparison of the result } \\
\text { with the generally accepted } \\
\text { standards }\end{array}$ & $\begin{array}{l}\text { Self-assessment on the basis } \\
\text { of application of the } \\
\text { individual achievement } \\
\text { standards }\end{array}$ \\
\hline
\end{tabular}

Secondly, during teaching practice, students had to study in detail the pedagogical methods used by their teachers and to evaluate the effectiveness of their teaching. Then while teaching their own classes they had to try using the most effective methods and to analyze their own results.

Thirdly, the collection of primary information was followed by the formation of a complex of essential personal and professional qualities of the teacher.

During the 2012-13 and 2013-14 academic years, students analyzed the pedagogical activity of 34 subject teachers. The average age of teachers was 37-40 years, predominantly female (28 of 34). Through the analysis of the teachers' pedagogical 
activity, the basic problem of the interaction "teacher - pupil" was formulated. The teacher in this model of relations realizes the over dominant position, acting as an arbitrator, a chief. Accordingly, the pupil fulfills a passive role of the attendant, who should not interfere with the teacher's classes and is obliged to strictly follow the instructions of the teacher.

The learning process, repeatedly observed by students in the course of study, can be described as follows:

- the teacher explains the essence of the task, its purpose and the expected result;

- the teacher shows the completion of each operation and activates the attention of the learner;

- the teacher explains the operation one more time, finding out at the same time what is understood and what is not;

- the teacher asks the pupil to perform each operation;

- the teacher gives an estimate of the pupil's actions, making the necessary adjustments;

- $\quad$ the pupil performs the required operations until makes no mistakes;

- the teacher sums up the process.

The observation and analysis of the teachers' pedagogical activity has showed that during classes only $1 / 4$ of the teachers (9) clearly distinguish the main ideas and the basic concepts. The rest of them do it in part, or do not do it at all. This leads to the low assimilation of knowledge by pupils. An example of this is the result of the analysis of the assimilation of some key concepts taught in the course "History of the Ancient World" such as "State", "class", "class structure of society" and some others, without which it is difficult to study history during the next years. Conversations with pupils allowed making a conclusion that pupils memorize well legends and myths of ancient Greece, information about the features of the Spartan education and the like. However, they have a poorly formed idea of the historical process.

Only a third of the teachers (11) have shown an alternative construction of the learning process, accompanied by a creative approach that involves the pupil in the process and allows taking an active participation in it. The most effective turned out to be the lessons where the teacher:

- led pupils to a contradiction and provided them with an opportunity to find a way of its solution;

- set out different points of view on the phenomenon that allowed pupils to form their own understanding of the problem;

- encouraged pupils to make comparisons, generalizations, conclusions;

- prepared tasks of the topical and research nature.

Stage 2: The formation of a substantial and methodical component of professional and didactic culture of the future history teacher. 
First, for this purpose, we have formulated the didactic objectives and performance indicators of the structural elements of the lesson (Table 2).

Table 2. Didactic Objectives and Performance Indicators of the Structural Elements of the Lesson

\begin{tabular}{|c|c|c|}
\hline Lesson stages & Didactic objectives & Performance criteria \\
\hline $\begin{array}{l}\text { 1. Actualization of } \\
\text { the results of previous } \\
\text { work }\end{array}$ & $\begin{array}{l}\text { Reproduction of knowledge, } \\
\text { actualization of personal } \\
\text { experience, building inter-subject } \\
\text { links, setting an adequate tune for } \\
\text { the assimilation of new } \\
\text { information }\end{array}$ & $\begin{array}{l}\text { Active } r \text { organized } \\
\text { communication between the } \\
\text { teacher and the pupil } \\
\text { according to the } \\
\text { reconstruction of previously } \\
\text { learned material }\end{array}$ \\
\hline $\begin{array}{l}\text { 2. Presentation of } \\
\text { new information }\end{array}$ & $\begin{array}{l}\text { Assurance of the perception, } \\
\text { comprehension and absorption of } \\
\text { knowledge }\end{array}$ & $\begin{array}{l}\text { Comprehension of the given } \\
\text { material and active pupils' } \\
\text { work with the material being } \\
\text { studied }\end{array}$ \\
\hline $\begin{array}{l}\text { 3. The practical part } \\
\text { under the guidance of } \\
\text { the teacher }\end{array}$ & $\begin{array}{l}\text { Establishing a rapid feedback for } \\
\text { the timely elimination or } \\
\text { prevention of mistakes }\end{array}$ & $\begin{array}{l}\text { Obtaining timely information } \\
\text { at the lesson on pupils' } \\
\text { assimilation of the basic } \\
\text { provisions of new } \\
\text { information }\end{array}$ \\
\hline $\begin{array}{l}\text { 4. Independent } \\
\text { practice of pupils }\end{array}$ & $\begin{array}{l}\text { Assurance of the assimilation of } \\
\text { new information and its } \\
\text { application in the changed } \\
\text { situation }\end{array}$ & $\begin{array}{l}\text { Pupils' active work, } \\
\text { discussion, exchange of } \\
\text { opinions and conclusions }\end{array}$ \\
\hline $\begin{array}{l}\text { 5. Self-control and } \\
\text { self-assessment }\end{array}$ & $\begin{array}{l}\text { Identification of the level of } \\
\text { quality and assimilation of } \\
\text { knowledge and the courses of } \\
\text { action, correction }\end{array}$ & $\begin{array}{l}\text { Obtaining } r \text { objective } \\
\text { information on pupils' } \\
\text { achievement of the expected } \\
\text { results }\end{array}$ \\
\hline $\begin{array}{l}\text { 6. Summing up the } \\
\text { results of the lesson }\end{array}$ & $\begin{array}{l}\text { Analysis and evaluation of the } \\
\text { success of the assimilation of } \\
\text { lesson objectives, formation of a } \\
\text { trajectory of follow-up work }\end{array}$ & $\begin{array}{l}\text { Adequacy of pupils' self- } \\
\text { assessment and the teacher's } \\
\text { assessment }\end{array}$ \\
\hline $\begin{array}{l}\text { 7. Information on } \\
\text { homework }\end{array}$ & $\begin{array}{l}\text { Assurance of the understanding } \\
\text { of the purpose, content and ways } \\
\text { of doing homework }\end{array}$ & $\begin{array}{l}\text { Implementation of necessary } \\
\text { and sufficient conditions for } \\
\text { the successful realization of } \\
\text { homework }\end{array}$ \\
\hline
\end{tabular}

Second, on the basis of the research the main conditions of the formation of future teachers' professional and didactic culture have been formulated. Stages 1 and 2 allowed identifying the focus and priorities of the training process.

Stage 3: The implementation of the main research results in the process of training of future teachers. 
This stage took one academic year (2014/15), during which the educational process in the experimental group (23 students) was built on the basis of the research results.

\section{Results and Discussion}

\section{Professional and didactic culture of the future history teacher}

Stages 1 and 2 of the research allowed outlining the focus and priorities of the future teacher training process. Analysis of the main research works in conjunction with the practical results obtained in the study helped to formulate the following features of the formation of professional and didactic culture of the future history teacher, which were taken into account in Stage 3.

Firstly, the formation of professional and didactic culture of the future history teachers depends on constant actualization of the valuable attitude towards pedagogical activity. Only a conscious attitude towards the chosen profession, understanding its significance will enable future teachers to effectively and consistently work on their professional development. It is important to have a clear understanding of the need to study and teach history. Each history teacher has a dual responsibility for the content of knowledge transmitted to pupils. First, as a teacher, he or she is responsible for the accuracy, completeness, adequacy of knowledge and the relevance of the competences under formation. Second, it is important to understand and accept the responsibility for the formation of a historical worldview which allows pupils to critically assess the events taking place in reality. Despite the abundance of information sources, the school and the teacher continues to be authorities in the field of knowledge translation. This is explained by a professional and practical approach to the formation of the content of classes: they should always be diverse and comply with the actual value orientations of pupils.

The research has shown that the authoritarian method of teaching still dominates in schools. Often the teacher only transmits the prepared learning content, monitors and evaluates the process of its assimilation. The negative result of the continuity of such a process is a prerequisite for the formation of passivity, consumerism, and lack of initiative and unconscious reproduction of knowledge. At the same time, the teacher who uses the humanistic model of teaching provides an active involvement of pupils in the learning process. This enables the pupil to operate with educational material that naturally entails a conscious and lasting assimilation of the content, development of the ability for self-learning and self-organization. Only the teacher, who objectively and fully represents the historical worldview, understands the relationship of events and takes the responsibility associated with each historical fact can generate a meaningful and critical attitude to the subject in pupils. In addition, the understanding of the responsibility for an untruthful and distorted historical view enables students to have a more serious motivation for the choice of the learning content, its presentation and makes them to search for the most appropriate and effective ways of conducting classes. All of this leads to a careful, conscious and not mechanical process of the preparation for classes. 
Secondly, in the process of preparation of the future history teacher it is necessary to form self-improvement skills, which certainly leads to the formation of the need for constant systematization of the newly received psychological and pedagogical knowledge. Self-improvement is the process of conscious development managed by the individual, wherein his or her qualities and abilities are purposefully formed and developed in subjective goals and interests. This is the highest level of human perfection, when the person, in his or her own interests, builds an educational environment in such a way that reaches a qualitatively new level of development. This is facilitated by the active learning attitude of students-future teachers of history: study of pedagogical, psychological, methodological and historical literature, along with participation in scientific conferences, professional competitions and project work.

A great advantage of the university in the process of preparation of future teachers is the possibility to control the trajectory of students' development. This allows to adjust the educational process and to make recommendations that will enable future teachers to build their own trajectory of self-development in the course of professional pedagogical activity on the basis of university experience. This is how the continuity and integrity of personal development is formed as well as the harmonization of pedagogical activities, integration of all of its aspects, personal orientation, alternativeness, freedom of choice (joint planning, differentiated tasks, etc.), awareness of professional and personal development during the pedagogical interaction (reflection, correction of one's own performance).

Thirdly, a modern component of the professional and didactic culture of every teacher is the ability to find innovative solutions to pedagogical situations. In the process of preparation of the future teacher of history, it is important to teach students not to be judgmental. It is necessary to teach them to give a critical evaluation of the historical events, processes, personalities, and the pupils' attitude towards them, and to use innovative methods to improve the efficiency of the assimilation of historical knowledge. Vocational guidance on innovation activities is formed during studying at higher educational institutions. This period can be called sensitive for the development of motivational and valuable attitude towards pedagogical innovations (Faizrakhmanova, \& Faizrakhmanov, 2015).

The study has showed that many teachers have a low level of formation of innovative behavior and willingness to innovate, which is largely a consequence of the traditional academic training. It is possible to formulate such a pedagogical phenomenon as the innovative behavior of the teacher - a set of external manifestations of his or her personality, which reveals the inner "I" (attitude, worldview, personality traits), aimed at changing the components of the modern education system. For future teachers of history the formation of such a component of professional and didactic culture is an integral part of professional development. Training of the modern teacher of history, capable of implementing the idea of the 
learner-centered education and addressing creatively the topical educational and socio-cultural issues, requires a special organization of the practical and intellectual activity.

It should be noted that the willingness to innovate is determined by the organization of the optimal innovative environment and educational activities oriented to innovation. For the formation of the innovative approach to solving educational problems, it is necessary to help students-future history teachers gain confidence in the relationship with classmates, teachers and propose the option of refraining from assessment that enhances the flow of ideas and the concentration on comprehension problems. Metaphors, analogies and search for new associations and connections can also be used. The possibilities of the creativity pursuit grow at the expense of unusual comparisons. During academic training, the work with metaphors not only encourages imaginative thinking but also stimulates the spontaneous creation of images and their purposeful apprehension. It is important to develop imagination and fantasy. This contributes to creating an environment of inner freedom. The important qualities for history teachers are open-mindedness and sensitivity to changes in the external environment, the breadth and richness of the perception of the world, which is the basis for the development of professional sensitivity.

Fourthly, the formation process of the professional and didactic culture of future history teachers should be based on the principle of intellectually and creatively productive cooperation and a cultural approach (Brookfield, 1987). According to the analysis of pedagogical literature, the cultural approach can be summarized as follows: the development and self-development of the personality should imply a social and cultural context; the content of education and family upbringing should be filled with culture. In addition, there are principles of the cultural environment of education and self-education; organization and management of cultural and creative activities of children and adults in educational institutions; freedom of cultural selfdetermination and self-development. Creative self-expression, collaboration and cocreation are the structural components of the process of preparation of the future teacher (Lipman, 1991). A very important role is played by the creative atmosphere in the learning process, the implementation of which is possible in the absence of internal barriers to creative manifestations. Thus, the development of cognitive and professional activity and the creative expression of future teachers can be enhanced by special assignments that encourage searching for multiple solutions.

And, fifthly, the formation of professional and didactic culture of the future teacher of history is a holistic and person-centered process. On the basis of the whole set of individual personal and professional performance criteria of the future history teacher there can be constructed an individual work flow chart of professional growth. Each person is unique as well as his or her personal qualities, abilities and professional qualities. The trajectories of professional development and advancement of each person should also be individual. 
Thus, the results of Stage 3 can be summarized as follows. During the school year, the educational process on history teaching in the experimental group (23 students) was based on the research results. Namely, during the implementation stage students were suggested to explore in practice a variety of traditional and non-traditional forms and methods of giving classes and studying topics. Moreover, the most effective were those lessons which suggested changing the form of the leading type of activity in the course of one lesson. In such a way, students had to prepare only theoretical materials on the topic, they were not told about the form of the lesson itself. Practice training started in the form of the game, and then could move to an organized form of discussion and group interactive work and be completed with creative individual homework. Such a change of activities allows actualizing the theoretical material every time from a new perspective, to look at the historical event from different perspectives, which definitely contribute to a more objective attitude towards the historical process. As shown by the final control activities, each student of the experimental group, in contrast to previous years, has shown a higher degree of assimilation of history teaching methods.

During the formation of the ideas of historical worldview, students were encouraged to rely on the causal relationships and the laws of the historical process, and during the formation of the conceptual apparatus - to gradually move from simple concepts to more complexes, constantly updating the gained knowledge. In the course of history teaching classes, special attention was also given to the variants of incomplete interpretation, distortion of historical facts and alternative forms of historical processes.

One of the students' tasks during the implementation stage was a complex coursework, which consists in the development and partial testing of the motivational, informative, control and final components of one of the modules in History during an open class in school. Each component must be educationally and psychologically justified.

As shown by the implementation of the research results in the process of teachers' preparation, the advantage of students is their openness to the formation of innovative behavior. All the students have demonstrated the desire and ability to realize innovative approaches to the organization of the educational process in their professional activities. Open lessons conducted by the experimental group students during the final teaching practice have showed a creative approach, an active involvement of pupils in the learning process and their high interest in the very form of classes. "The enthusiasm of the teacher (student) generates the enthusiasm of the learner" - this idea, formulated by the experimental group students, has been reflected and implemented in practice.

The results of the complex coursework in the experimental group are shown in Figure 1. 


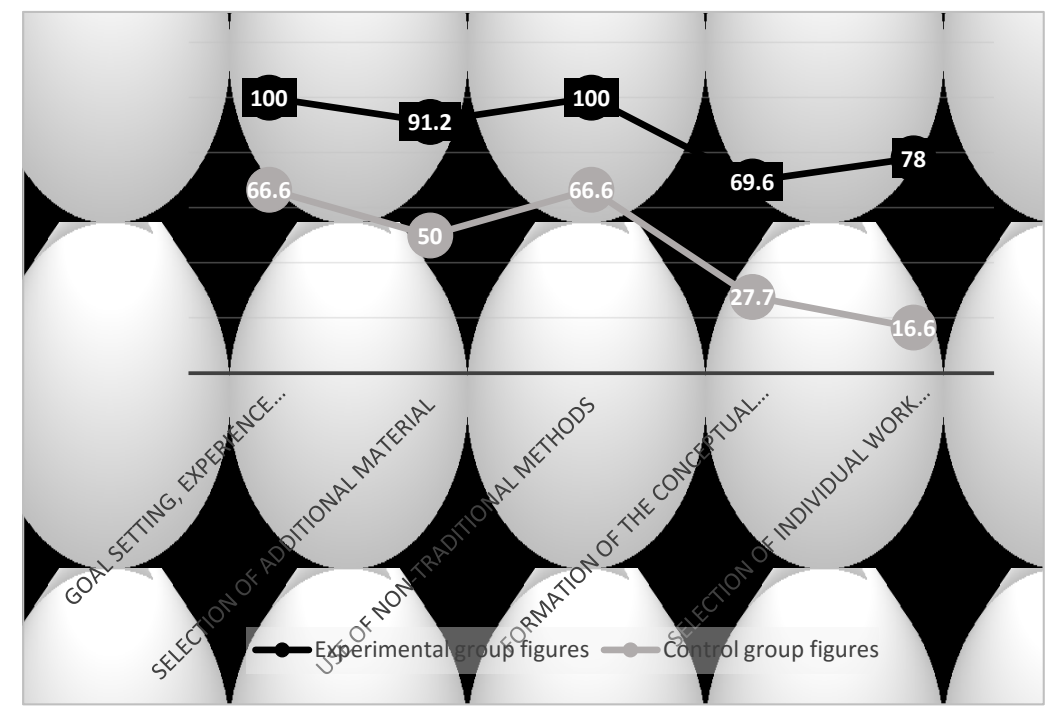

Figure 1. Comparative Figures of the Coursework Results on the Basis of Teaching Practice

The students of the experimental group have shown the following results:

- $100 \%$ (23) of the students illustrated intra- and interdisciplinary connections in the goal setting stage and updated pupils' personal experience;

- 91.2\% (21) of the students carefully selected the theoretical and factual material and attracted a variety of sources;

- $100 \%$ (23) of the students demonstrated the possession of non-traditional teaching methods and used them advisably and reasonably in class;

- $69.6 \%$ (16) of the students paid special attention to the work on the conceptual apparatus in various forms;

- 78\% (18) of the students offered multiple variants of individual work for pupils.

The formation of the individual teaching style of almost each student can be regarded as the positive result of the implementation stage. Moreover, all 23 students received high marks from the subject teachers and the best pupils' comments on the results of the teaching practice.

It should be noted that 12 out of 23 graduates of the experimental group have started their professional activity in secondary schools. Therefore, more long-term results can be seen on the basis of their professional pedagogical certification. 
Based on the above, the use of two levels of the interconnected chain "purposemeans-result" can be recommended in the process of preparing future teachers. The first - standard - level has traditionally been used in the pedagogical process. The second - individual - level allows determining the progress in the individual professional development of each student (Table 3).

Table 3. Interconnection Levels of the Chain "Purpose-Means-Result"

\begin{tabular}{|l|l|l|l|}
\hline & Purpose & Means & Result \\
\hline $\begin{array}{l}\text { First level } \\
\text { standard }\end{array}$ & $\begin{array}{l}\text { Evaluate the quality } \\
\text { of the compulsory } \\
\text { minimum of subject } \\
\text { assimilation }\end{array}$ & $\begin{array}{l}\text { Regular assessment } \\
\text { standards grade } \\
\text { rating) }\end{array}$ & $\begin{array}{l}\text { Level of the } \\
\text { assimilation of the } \\
\text { compulsory } \\
\text { minimum } \\
\text { curriculum }\end{array}$ \\
\hline $\begin{array}{l}\text { Second level }- \\
\text { individual }\end{array}$ & $\begin{array}{l}\text { Evaluate the quality } \\
\text { of the individual } \\
\text { development of the } \\
\text { student }\end{array}$ & $\begin{array}{l}\text { Individual assessment } \\
\text { standards }\end{array}$ & $\begin{array}{l}\text { Intensity of the } \\
\text { personality } \\
\text { development }\end{array}$ \\
\hline
\end{tabular}

\section{Critical thinking as an element of professional and didactic culture of the future teacher}

Professional and didactic culture should be based on critical thinking of the teacher. An indispensable condition for critical thinking is the knowledge of the rules of logic. To learn to think critically for the student is to follow the rules of logic. It is important to master the algorithm of the critical approach to the process of teaching. In this case, some skills required for the development of students' critical thinking are suggested (Halpern, 2003). The knowledge of the ethics of criticism and the formation of critical thinking culture through the organization of debates, discussions, writing reviews and participation in team decisions of educational problems should be considered as an important aspect of the development of critical thinking. The main purpose of the formation of critical thinking of the future teacher is to expand the intellectual competence in order to deal effectively with social, scientific and practical problems. The objectives of the formation of critical thinking differ according to the age of students, the level of knowledge and previous experience (Dewey, 1999).

The concept of "critical thinking" includes a set of key skills such as observation, the ability to interpret, analyze, make findings and evaluate (Tarasiuk, \& Kopylov, 2013). Critical thinking applies logic and is based on metacognition (according to the concept of J. Flavell, it is the ability to analyze one's own thinking strategies "to think about thinking" - and to manage one's own cognitive activity) (Shakirova, 2006) and broad criteria of intelligence, such as clarity, credibility, precision, relevance, depth, horizons and justice. Creative imagination, values and emotional 
intensity, expressed to a lesser extent, also form an integral part of critical thinking (Aronowitz, \& Giroux, 1991) (Table 4).

Table 4. Stages of Development as a Critical Thinker According to E.N. Volkov (Facione)

\begin{tabular}{|l|l|}
\hline Stages of critical thinking & Manifestation of critical thinking \\
\hline 1. Non-reflexive thinker & $\begin{array}{l}\text { Manifested in the awareness of significant problems in } \\
\text { one's thinking }\end{array}$ \\
\hline 2. Puzzled thinker & $\begin{array}{l}\text { Manifested in the awareness of the problem in one's } \\
\text { thinking }\end{array}$ \\
\hline 3. Starting thinker & $\begin{array}{l}\text { Manifested in the attempt to improve but without regular } \\
\text { practice }\end{array}$ \\
\hline 4. Practicing thinker & $\begin{array}{l}\text { Manifested in the recognition of the need for regular } \\
\text { practice }\end{array}$ \\
\hline 5. Advanced thinker & $\begin{array}{l}\text { Manifested in the advancement in accordance with one's } \\
\text { practice }\end{array}$ \\
\hline 6. Thinking master & $\begin{array}{l}\text { Manifested in the fact that the skilled and insightful } \\
\text { thinking becomes a necessary part of nature }\end{array}$ \\
\hline
\end{tabular}

M. Lipman distinguishes four stages or steps in the critical reflection of practice:

1) criticism of the practice of one's colleagues;

2) self-criticism;

3) correction of the practice of others;

4) self-correction.

He says that reflection on practice forms the basis for the creation of the improved practice, and the latter, in turn, will initiate further reflection and the subsequent correction of practice (Butenko, \& Khodos, 2002). Critical thinking, in his view, consists of skills (well-founded judgment, expansion of alternatives and possibilities, performance in ideation - in total 30 skills are given) and certain dispositions (belief in the need for self-correction of the research method, attention to the research process; account of other points of view; willingness to be critical not only towards others but also towards oneself). All this in a complex Lipman calls the dedication to the research spirit. The developed algorithm of the formation of critical thinking among students is based on the educational development technology of critical thinking, developed by American educators J. Steele, K. Meredith and Ch. Temple (Lipman, 1991).

Step 1: Challenge phase - challenge of the existing knowledge on the subject under study, activation of students and motivation for further work. Type of activity: making a list of the "known information"; narration - assumption by keywords; systematization of the material (preliminary clusters, tables); true-false statements; confused logic chains.

Step 2: Understanding - saving interest in the topic while working directly with the new information, the gradual promotion of the "old" knowledge to "new". 
Type of activity: active reading techniques: text marking, search for answers (Gregory, 2002).

Step 3: Reflection - creative processing, analysis of the studied information. Learners connect "new" and "old" information, using the knowledge gained at the stage of thinking. Type of activity: filling clusters, tables; establishing causal relationships between information blocks; return to keywords, true-false statements, answers to the given questions, the organization of discussions, etc.

\section{Conclusion}

Thus, the formation of professional and didactic culture as a whole and the critical thinking of the future teacher, in particular, should lead to the following results:

- an increase in the motivation of students for the educational process, the process of preparation for the future profession;

- an increase in students' thinking abilities, flexibility of their thinking, its switch from one type to another; operate them;

- development of the ability to independently design, build concepts, and to

- development of the ability to transfer the author's information to others, subject it to correction, understand and accept the point of view of another person;

- development of the ability to analyze the information. Obtaining new information, students-future teachers must learn to consider it from different perspectives and to draw conclusions as to its accuracy and value (Banning, 2005).

Students-future teachers with a versatile stock of knowledge and a certain social experience are able to absorb integrative knowledge and skills translated into competences if they have a motivation and a positive attitude towards an active working life. During the formation of critical thinking skills, teachers can put the problems of the formation of integrative mental competences on the basis of logic, problem and critical thinking.

Thus, the combination of the process of future teachers' preparation and the process of the formation of their professional and didactic culture would enhance the effectiveness of such training. As the result, the graduate would have a conscious picture of his or her future profession and a well-planned work flow chart of his or her professional growth on the basis of personal qualities and individual success.

The process of future teachers' preparation and the formation of their professional and didactic culture represent a unified system of actions aimed at:

- the gradual development of the structural and functional components of a professional and didactic culture model;

- the formation and development of teachers' personal qualities;

- the disclosure of teachers' creative possibilities;

- the translation of potential features into current; 
- the creation of the conditions for the realization of teachers' creative potential in the professional and didactic activity.

Given the above, it becomes obvious that in the current context of the educational process it is necessary to implement the purposeful formation of the didactic culture of the teacher and to empirically determine the effective technologies and methods of its development.

\section{References}

Akhmetov, L.G., Faizrakhmanov, I.M. \& Faizrakhmanova, A.L., 2013, "Emotional component of communicational activity in the process of making a future teacher ready to competitive relations", Middle-East Journal of Scientific Research 17(2), 173-176.

Akhmetov, L.G., Faizrakhmanov, I.M. \& Faizrakhmanova, A.L., 2014, "Features of use of direct communicative interaction in the course of formation of professionally significant competence". Paper presented at the 3-rd International Congress on Interdisciplinary Behavior and Social Science, Bali, Indonesia, 107-111.

Aronowitz, S. \& Giroux, H., 1991, "Postmodern education: Politics, culture and social criticism", Minneapolis-Oxford: University of Minnesota Press, 205 p.

Banning, M., 2005, “Approaches to teaching: current opinions and related research", Nurse Education Today 25(7), 502-508.

Brookfield, S.D., 1987, "Developing Critical Thinkers. Challenging Adults to Explore Alternative Ways of Thinking and Acting", California Open University Press, 1-51.

Gregory, J., 2002, "Facilitation and facilitator style", In P. Jarvis (Ed.), The Theory and Practice of Teaching, London: Kogan Page, 79-93.

Halpern, D., 2003, "Thought and Knowledge: An Introduction to Critical Thinking”, New Jersey: Lawrence Erlbaum Associates, Inc., Publishers.

Hendry. G.D., Frommer, M. \& Walker, R.A., 1999, "Constructivism and problem-based learning”, Journal of Further and Higher Education 23, 359-371.

Levina, E.Y., Akhmetov, L.G., Latipova, L.N., Mirzagitova, A.L., Mirzanagimova, F.I., Latipov, Z.A. \& Masalimova, A.R., 2015, "Diagnostics of educational activity quality on the basis of qualitative methods", Asian Social Science 11(4), 246-252.

Lipman, M., 1991, "Thinking in education”, Cambridge: Cambridge university press.

Mirzagitova, A.L. \& Akhmetov, L.G., 2015, "Self-development of pedagogical competence of future teacher, International Education Studies 8(3), 114-121.

Mirzagitova, A.L., Mukhametgaliyeva, S.H. \& Tirigulova, R.H., 2015, "Realization of competence-based approach in preparation of the competitive specialist. The Proceedings of 6th World Conference on Educational Sciences", Procedia - Social and Behavioral Sciences 191, 1938-1940.

Butenko, A.V. \& Khodos, E.A., 2002, "Critical thinking: Method, theory, practice [Study guide]", Moscow: Miros. $176 \mathrm{p}$.

Facione, P.A. Critical thinking: A statement of expert consensus for purposes of educational assessment and instruction, Executive Summary, Translated by E. N. Volkov, The California Academic Press. 234 p. Retrieved from http://evolkov.net/critic.think/basics/delphi.report.html

Dewey, J., 1999, "Psychology and pedagogy of thinking (How we think)", trans. from English by N.M. Nikolskaya, in Rasskazov, U.S. (Ed.). Moscow, Labyrinth. 
Ksenzova, G.Y., 2004, "Psychology of teacher's labor: Textbook for the system of advanced training and retraining of educators", Tver: Lily Print, 42.

Samokhin, Y.S., 2012, "On the responsibility of the teacher for the design and research of the pupil”, Slovo (Pedagogy Series), retrieved from http://www.portal-slovo.ru/

Tarasiuk, O.V. \& Kopylov, S.N., 2013, "Content design of general professional disciplines in the formation of the professional competence of college students: theoretical and practical aspects", Ekaterinburg: RGPPU, 13.

Faizrakhmanova, A.L. \& Faizrakhmanov, I.M., 2015, “Technology of creative workshops in the process of training of the future technology teacher", Modern problems of science and education 1. Retrieved from http://www.science-education.ru/121-18502

Shakirova, D.M., 2006, "Pupils and students' critical thinking formation: model and technology”, Educational Technology \& Society 9(4), 284-292. 